High Performance and Optimum Design of Structures and Materials IV 31

\title{
REVIEW OF AUTOGENOUS AND AUTONOMOUS SELF-HEALING CONCRETE TECHNOLOGIES FOR MARINE ENVIRONMENTS
}

\author{
MARWAN SUHAIL SUNAKH ZABANOOT \\ Department of Architecture and Civil Engineering, University of Bath, UK
}

\begin{abstract}
Most structures use concrete as a main material in their construction work. Despite its low cost and high compressive strength properties, it suffers from disadvantageous cracks on surfaces when it is hardened, which be costly to repair. Europe spends almost half of its construction budget annually on structure repairs. Fortunately, today's science had reached a level of engineered solutions to experimentally overcome this dilemma. In order to reduce the repair expenses of concrete cracks, a solution of self-healing concrete is introduced. The process of self-healing cracks in hardened concrete depends on including - in most cases - agents in the cementitious compositions such as minerals, bacteria and microcapsules containing adhesive materials. The actual challenge to be faced is when it comes to concrete construction in marine environments like seashores, such aggressive mediums uncover various considerations due to the biological and chemical behaviors in those places. This paper aims to provide a literature body based on research to review different types of self-healing technologies and their durability for reinforced concrete (RC), especially for structures in marine environments in both approaches: autogenous and autonomous. As seen from the literature body, the concluded methods for healing concrete cracks include the Ground Granulated Blast Furnace Slag (GGBFS), partially substituted with cement in the mixture. In addition to that, the utilization of the autonomous Bactria-based self-healing is another smart method that the literature lately revealed.
\end{abstract}

Keywords: self-healing concrete, autogenous, autonomous, marine environments, GGBFS, SAP particles, polyurethane.

\section{INTRODUCTION}

According to Joshi et al. [1], "As nearly $80 \%$ of world's infrastructure is built in reinforced concrete, their maintenance needs a huge recurring investment that few countries in the world can afford. There is a worldwide effort for sustainable technologies for maintenance of infrastructures that would offer economy without undue environmental or social costs" [1]. Marine environment is considered an extreme and aggressive environment for establishing concrete structures. Such environments require special precautions and engineered procedures for the reinforced concrete to withstand, for example, the low temperatures of sea water, tidal effects, pressure, biological life, etc. Marine environments contain high percentages of chloride concentration. The reinforced concrete is the type of structure used in such environments. The durability of reinforced concrete is affected negatively by chloride as it is harmful due to corrosion affect. When cracks occur in $\mathrm{RC}$ in marine environment, that will facilitate the penetration of chloride into the hardened material which will make the corrosion even faster [2]. As noticed, cracks in concrete structures in sea environments have the major cause for initiating a continuous damage to the internal parts of the structure. The extent to which the chloride penetration into the cracks can reach, is dependent on several variables. For example, width and depth of the crack itself. Also, the type of cementitious mixture and its composition [2]. Aggressive agents such as Chloride, Magnesium and Sulfate can damage the solid concrete and eventually will lead to shortening its service life [3]. Essentially, the sizes of the cracks in the concrete are playing a crucial role as that is main interface for ingress of any liquids or chemical particles to the inside. "To limit the crack 
width below $50 \mu \mathrm{m}$ in order to avoid chloride penetration. So, it seems that in marine environments, the crack widths should be limited more in order to maintain or increase the durability of the structures" [2], [4].

The technology of using self-healing concrete is applicable in the case of marine environments, but certainly will require exceptional measures in order to overcome the obstacles, contain all the variables and comprehend the conditions. As soon as cracks in reinforced concrete are noticed, it's essential to repair them as they can cause serious damages. In marine environments, the structure is even highly vulnerable due to chloride penetration into the cracks which will accelerate the corrosion process for the rebars. The repair process of those cracks in marine environments are so expensive and, in some situations, non-operable because of the inaccessibility. As a result, it is significant to use technologies of self-healing concrete in this case as they offer recovery for those cracks without outer intervention. The usage of water repellent agents along with corrosion inhibitors during mixing of concrete, can effectively delay the corrosion of reinforcement which is a user-friendly method. The throwback of this method is that some properties of concrete can be affected in a negative way like setting time and compressive strength [5].

For now, many researches are investigating in the science of self-healing concrete in marines and the results of those experiments are showing promising future and a scientific base to start for implementation. Most of recent researches have concluded results on self-healing concrete made in tap water, however that is not quite similar to the effects on cracks while being in marine water due to higher concentration of $\mathrm{Cl}$., $\mathrm{SO}_{4}{ }^{2-}$ and $\mathrm{Mg}^{2+}$ ions in sea water [3]. "Concrete in the tidal or splash zones of a marine environment experiences wet-dry cycles, which may also influence the kinetics of the autogenous self-healing of cracks" [3], [6]. As it seen from the previous review body, there are several factors that can determine the durability of concrete in marine environments. However, self-healing solutions will be discussed in detail in the next sections.

\section{OVERVIEW OF SELF-HEALING CONCRETE TYPES}

This section will showcase different types of self-healing methods in concrete along with general overview about them. A great deal of literature body has been provided by recent researchers who have studied the modern techniques of such "smart" concrete in order to overcome the inevitable setback of cracks in concrete. Reinforced concrete is vulnerable for cracks due to many reasons like creep, thermal change due to temperature difference, external loading, shrinkage and freeze-thaw cycles [7]. "The cracks have a negative impact on safety and may even cause serious accidents" [8]. The technologies of self-healing concrete are emphasizing their role in repairing cracks that could happen for various reasons. Adding to that, advanced performance of many different structural materials. For instance, adding capsules of fiber glass containing adhesives into the concrete mixtures can play a healing role when cracks occur. However, this method has its limitations as the fiber glass itself is vulnerable to breakage during early stages of hardening [8]. "In general, self-healing in cementitious materials is classified in two main groups: intrinsic healing and capsule based healing" [2], [9]. This section will present the two types (autogenous and autonomous) in addition to another recent type (vascular self-healing).

\subsection{Autogenous intrinsic self-healing methods}

The intrinsic self-healing methods are defined as the autogenous healing in concrete due to its composition of various cementitious components in the mixture. This approach is dependent on the properties that make up the mixture itself. When the cracks occur, water 
is an essential factor (Fig. 1) for autogenous healing of concrete [9]. Addition of fly ash and bacterial spores into the cementitious composition, for instance, can explain the autogenous self-healing of concrete. When adding fly ash as pozzolanic materials instead of cement in the concrete mixture, hydration of the un-hydrated parts should promote the autogenous healing of concrete cracks when occurred. Furthermore, complementing bacterial spores into the cementitious mixture and after the hardening and cracking, the water ingress into the crack to stimulate a chemical reaction that will result an agent to fill that crack [9]. Based on the experiment by Liu et al. [3], when they tested the crack healing with immersing in water, "It is conceivable that water plays an essential role in autogenous self-healing as water was the medium for the diffusion of ions and the formation of reaction products." They concluded that wet-dry cycles have an effect of efficiency of autogenous self-healing of crack in the cement paste. Cycle of 12 hours wetting and then 12 hours drying has a higher efficiency than cycle of 1 hour of wetting and 23 hours of drying.

\subsection{Autonomous self-healing}

The second type of crack healing in concrete is the type that includes closed capsules (either spherical or cylindrical) shown in (Fig. 2) that contain a healing agent. When crack happens, the capsule breaks and the inside agent (sometimes special Bacteria) fills the crack due to gravitation forces [9]. Generally, this type is called autonomous self-healing. "To facilitate the production of self-healing concrete, encapsulated healing agents are preferably added to the concrete mix during preparation" [9]. The efficiency of such encapsulated agents can be observed in the aggressive conditions related to temperatures that can produce very difficult cracks to handle. According to Van Tittleboom and De Belie [9] and May's [10] literature bodies, "When temperature differences and cyclic loads cause the crack to grow wider or become more narrow, elastic behavior of the hardened agent is wanted. In order not to lose the bond between the repair agent and the cementitious matrix, and thus preserve the crack sealing ability." On the other hand, water as medium can have other significance as the autonomous healing action can start with different types of trigger mechanisms. For example, the ingress of liquids into the crack, however that has some throwbacks. "A disadvantage is that as long as the required agent does not intrude into the crack, healing is not activated. In the period between formation of damage and activation of healing, degradation of the concrete matrix can still occur" [9].

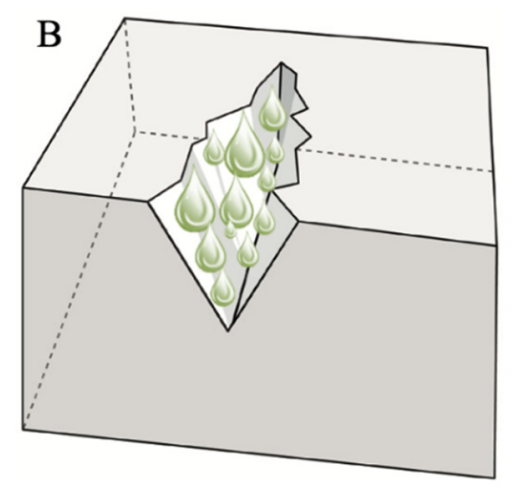

Figure 1: Autogenous self-healing in concreate cracks due to water supply. (Source: [9].) 


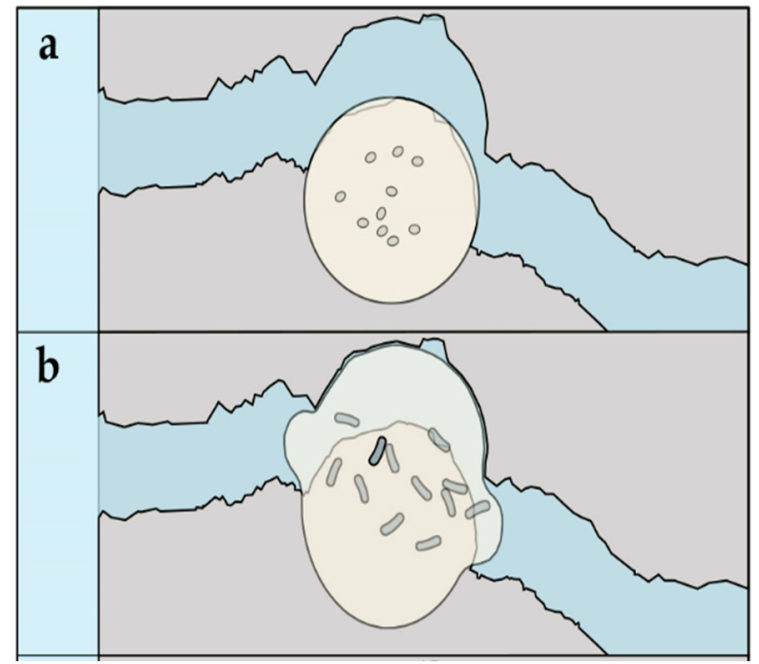

Figure 2: Autonomous self-healing concrete methods. (a) The spherical capsules with agents; and (b) The cylindrical capsules with agents. (Source: [11].)

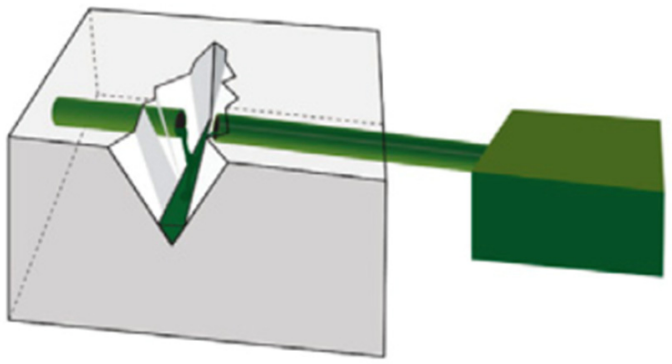

Figure 3: Vascular method for self-healing concrete using external container with healing substances. (Source: [12].)

\subsection{Vascular self-healing}

The third type has an external tank that contains a healing agent, a vascular tube is connected from the tank into the concrete and laid as network over the span of the concrete. Once the concrete is cracked, the agent flows into it through the vascular channels. This approach is continuous and repetitive properties as the external tanks could be always refilled with healing agents [9]. This approach is considered least used among self-healing concrete as it relatively expensive and demands a suitable space for the tank (Fig. 3) to store the healing agent. Simultaneously, the storing tanks need certain conditions for the healing agents to withstand prior to usage. 


\section{APPRAISAL OF SELF-HEALING CONCRETE IN MARINE ENVIRONMENT}

Since the marine environment is considered an aggressive medium for concrete, resulting tremendous damaging in case of cracks, serious measurements should be taken in consideration when applying self-healing solutions. Next, a presentation of five self-healing modern techniques will be shown that are suggested as solutions for the problem based on most recent body literature.

\subsection{Using autogenous self-healing}

"In case of marine infrastructures in tidal zones, the presence of magnesium sulfates may enhance the crack sealing by means of brucite precipitation. These processes will result in reduced chloride penetration rates" [5]. For minor cracks, autogenous healing is the dominant solution as long as the water accessibility is able to hydrate the un-hydrated parts to accelerate the process. However, chloride from seawater will lower the chances of direct healing [6]. The maximum width to which autogenous methods of concrete cracks healing can work is between 200-300 $\mu \mathrm{m}$. On the other hand, the autonomous healing can heal cracks that extend to $500 \mu \mathrm{m}$. Moreover, for the capsules that contain bacterial agents, it was reported that this approach could heal concrete cracks up to $970 \mu \mathrm{m}$ [12]-[15].

\subsection{Using sap particles (autonomous)}

Super Absorbent Polymers (SAP), are particles that are added to the cementitious mixtures in order to enhance the mixture with water. SAP particles have the capability of liquid absorption and after swelling they can work as gel for cracks. The whole process starts during the mixing of concrete components, the SAP particles absorb some water, which is added into the cementitious mixtures. As a result, pores appear, which makes it easier to predict the locations of cracks as they will most likely follow the path of the pores. The ingress of moisture and wetness into the cracks will make SAP particles absorb them and swell until a gel is resulted as the agent for autonomous self-healing of concrete [9], [16]-[19]. Using SAP particles in the cementitious mixture to make concrete with better self-healing approaches is not recommended for marine structures as the seawater will seal the cracks which will stop the SAP particles from swelling and limit the autonomous self-healing of those cracks. As a result, this shortage will affect the durability of concrete in marine environments [9], [16].

\subsection{Using polyurethane (autonomous)}

Because of magnesium sulfates' presence in marine infrastructures, the cracks may be repaired by brucite precipitation due to seawater. In case the width of the crack is over $10 \mu \mathrm{m}$, the penetration of chloride into the mixture will be faster, which will shorten the life span of the reinforced concrete. The solution to that is laid in involving the mechanisms of autonomous healing. Adding polyurethane capsules can provide self-healing efficiency of $75 \%$ for cracks with $300 \mu \mathrm{m}$ width towards the diffusion of chloride into them [2]. "Autonomous crack healing of mortar samples by means of encapsulated polyurethane has a beneficial influence on the resistance against chloride diffusion for crack widths around 100 $\mu \mathrm{m}$ and $300 \mu \mathrm{m}$ " [2]. According to Maes et al. [2], their experiment was more focused on samples of mortar rather than reinforced concrete when adding the polyurethane into to mixture, however they resulted in very encouraging results in terms of durability. "autonomous crack healing by means of encapsulated polyurethane is able to improve the durability. This finding could be used to prove that an important service life extension of 
structures can be achieved with self-healing cementitious materials in chloride-containing environments" [2].

\subsection{Using GGBFS (autonomous)}

According to Kim et al. [20], Shi et al. [21] and Ben Haha et al. [22], "Ground granulated blast furnace slag (GGBFS) has been widely used as a raw material for alkali-activated composites. It contains a higher amount of amorphous silica, which makes it an excellent reactive material." The activator's job is to provide strength due its chemical reactions with (GGBFS). Calcium hydroxide-based activator used in the experiment by Kim et al. [20] due to its efficiency, low cost and high durability comparing to other activators [23], [24]. The results of the experiment by Kim et al. [20], concluded that autogenous self-healing method is the most efficient method for healing cracks happening in marine structures. However, it requires special methodology that involves replacing almost $50 \%$ of the Portland cement with Ground Granulated Blast Furnace Slag along with utilization of $\mathrm{Ca}(\mathrm{OH})_{2}$ in the form of coated granules as activators. Not only that, but as well as being durable since the lab results showed that the cracks were fully filled after 39 days.

\subsection{Using bacteria-based self-healing (autonomous)}

The technology of bacteria-based self-healing for cementitious configuration in marine environments with low temperature, is a promising method to solve the problems of cracks in aggressive environments. The bacterial behavior provides a biological perspective for this approach for emphasizing the concept of autonomous self-healing. Basically, when seawater ingress into the crack, the beads of bacteria-based in the structure start to swell resulting a blockage that releases the bacteria. At once, the spores start to germinate based on chemical reactions with other existing minerals which will lead eventually to healing the crack. Also, this technique is to be considered very cost-effective [11]. Based on the experiment by Palin et al. [11], "The composite displayed an excellent crack-healing capacity, reducing the permeability of cracks $0.4 \mathrm{~mm}$ wide by $95 \%$, and cracks $0.6 \mathrm{~mm}$ wide by $93 \%$ following 56 days of submersion in artificial seawater at $8^{\circ} \mathrm{C}$." The compressive strength for this technology is considered to be very reliable material in construction [11], [25].

\section{RECOMMENDATIONS AND CONCLUSION:}

The advanced technologies are yet to be implemented into today's concrete structures especially in the marine environments where opportunity of sea water exposure can affect negatively resulting in irreversible cracks. Nevertheless, finding the possible solutions for concrete cracks is still in the experimental phase. Based on the data obtained from literature, the suggested methods to be adopted for cracks in concrete are the autogenous self-healing using GGBFS, due to its easiness of usage and durability in marine environments. A matter to be considered as well is to illustrate a wholistic study of the tidal data of the construction site in order to examine the continuous effects on hardened composition.

The other method which is also can be adopted and relative to the scale of any project, is using the autonomous Bacteria-based self-healing. This method has shown promising success experimentally even in low temperature of sea water and it requires a labor-intensive skill.

A recommended experiment to be investigated in future is to have the GGBFS cement combined with the bacteria-based self-heling technology to examine the effects of sea water on the cracks of this new composition for RC structures in marine environments. 


\section{REFERENCES}

[1] Joshi, S., Goyal, S., Mukherjee, A. \& Reddy, M.S., Microbial healing of cracks in concrete: A review. Journal of Industrial Microbiology and Biotechnology, 44, pp. 1511-1525, 2017. https://doi.org/10.1007/s10295-017-1978-0.

[2] Maes, M., Van Tittelboom, K. \& De Belie, N., The efficiency of self-healing cementitious materials by means of encapsulated polyurethane in chloride containing environments. Construction and Building Materials, 71, pp. 528-537, 2014. https://doi.org/10.1016/j.conbuildmat.2014.08.053.

[3] Liu, H., Huang, H., Wu, X., Peng, H., Li, Z., Hu, J. \& Yu, Q., Effects of external multiions and wet-dry cycles in a marine environment on autogenous self-healing of cracks in cement paste. Cement and Concrete Research, 120, pp. 198-206, 2019. https://doi.org/10.1016/j.cemconres.2019.03.014.

[4] Van Den Heede, P., Maes, M. \& De Belie, N., Influence of active crack width control on the chloride penetration resistance and global warming potential of slabs made with fly ash + silica fume concrete. Construction and Building Materials, 67, pp. 74-80, 2014. https://doi.org/10.1016/j.conbuildmat.2013.10.032.

[5] De Belie, N., Van Tittelboom, K., Maes, M., Van Belleghem, B. \& Van Den Heede, P., Self-healing concrete in aggressive environments. Proceedings of the 1st International Conference on Construction Materials for Sustainable Future, 42-48, 2014. https://biblio.ugent.be/publication/8530131/file/8530134.pdf.

[6] Maes, M., Snoeck, D. \& De Belie, N., Chloride penetration in cracked mortar and the influence of autogenous crack healing. Construction and Building Materials, 115, pp. 114-124, 2016.

[7] Van Belleghem, B., Kessler, S., Van den Heede, P., Van Tittelboom, K. \& De Belie, N., Chloride induced reinforcement corrosion behavior in self-healing concrete with encapsulated polyurethane. Cement and Concrete Research, 113, pp. 130-139, 2018. https://doi.org/10.1016/j.cemconres.2018.07.009.

[8] Dong, B. et al., Electrochemical impedance study on steel corrosion in the simulated concrete system with a novel self-healing microcapsule. Construction and Building Materials, 56, pp. 1-6, 2014. https://doi.org/10.1016/j.conbuildmat.2014.01.070.

[9] Van Tittelboom, K. \& De Belie, N., Self-healing in cementitious materials-a review. Materials, 6(6), pp. 2182-2217, 2013. https://doi.org/10.3390/ma6062182.

[10] Mays, G.C., Adhesion between polymers and concrete Bonding protection repair. International Journal of Adhesion and Adhesives, 7(1), pp. 50, 1987. https://doi.org/10.1016/0143-7496(87)90056-x.

[11] Palin, D., Wiktor, V. \& Jonkers, H.M., A bacteria-based self-healing cementitious composite for application in low-temperature marine environments. Biomimetics, 2(4), pp. 13, 2017. https://doi.org/10.3390/biomimetics2030013.

[12] Tang, W., Kardani, O. \& Cui, H., Robust evaluation of self-healing efficiency in cementitious materials - A review. Construction and Building Materials, 2015. https://doi.org/10.1016/j.conbuildmat.2015.02.054.

[13] Edvardsen, C., Water permeability and autogenous healing of cracks in concrete. $A C I$ Materials Journal, 96(4), pp. 448-454, 1999. https://doi.org/10.14359/645.

[14] Wang, J.Y., Snoeck, D., Van Vlierberghe, S., Verstraete, W. \& De Belie, N., Application of hydrogel encapsulated carbonate precipitating bacteria for approaching a realistic self-healing in concrete. Construction and Building Materials, 68, pp. 110119, 2014. https://doi.org/10.1016/j.conbuildmat.2014.06.018. 
[15] Wang, J. Y., Soens, H., Verstraete, W. \& De Belie, N., Self-healing concrete by use of microencapsulated bacterial spores. Cement and Concrete Research, 56, pp. 139-152, 2014. https://doi.org/10.1016/j.cemconres.2013.11.009.

[16] Lee, H.X.D., Wong, H.S. \& Buenfeld, N.R., Potential of superabsorbent polymer for self-sealing cracks in concrete. Advances in Applied Ceramics, 109(5), pp. 296-302, 2010. https://doi.org/10.1179/174367609X459559.

[17] Kim, J. S., \& Schlangen, E., Self-healing in ECC stimulated by SAP under flexural cyclic load. Proceedings of 3rd International Conference on Self Healing Materials, Bath, UK, pp. 27-29, 2011. https://doi.org/10.1002/nme.2772.

[18] Snoeck, D., Steuperaert, S., Van Tittelboom, K., Dubruel, P. \& De Belie, N., Visualization of water penetration in cementitious materials with superabsorbent polymers by means of neutron radiography. Cement and Concrete Research, 42(8), pp. 1113-1121, 2012. https://doi.org/10.1016/j.cemconres.2012.05.005.

[19] Snoeck, D., Van Tittelboom, K., Steuperaert, S., Dubruel, P. \& De Belie, N., Selfhealing cementitious materials by the combination of microfibers and superabsorbent polymers. Journal of Intelligent Material Systems and Structures, 25(1), pp. 13-24, 2014. https://doi.org/10.1177/1045389X12438623.

[20] Kim, H.G., Atta-ur-Rehman, Qudoos, A. \& Ryou, J.S., Self-healing performance of GGBFS based cementitious mortar with granulated activators exposed to a seawater environment. Construction and Building Materials, 188, pp. 569-582, 2018. https://doi.org/10.1016/j.conbuildmat.2018.08.092.

[21] Shi, C., Jiménez, A.F. \& Palomo, A., New cements for the 21st century: The pursuit of an alternative to Portland cement. Cement and Concrete Research, 2011. https://doi.org/10.1016/j.cemconres.2011.03.016.

[22] Ben Haha, M., Le Saout, G., Winnefeld, F. \& Lothenbach, B., Influence of activator type on hydration kinetics, hydrate assemblage and microstructural development of alkali activated blast-furnace slags. Cement and Concrete Research, 41(3), pp. 301310, 2011. https://doi.org/10.1016/j.cemconres.2010.11.016.

[23] Shi, C. \& Day, R.L., Comparison of different methods for enhancing reactivity of pozzolans. Cement and Concrete Research, 31(5), pp. 813-818, 2001. https://doi.org/10.1016/S0008-8846(01)00481-1.

[24] Shi, C., Krivenko, P.V. \& Roy, D., Alkali-Activated Cements and Concretes, CRC Press: London, 2006. https://doi.org/10.4324/9780203390672.

[25] Pataky, K. et al., Measurement of mechanical properties of alginate beads using ultrasound Abstract : Mots clefs. Biomaterials, 24(3), pp. 1-6, 2001. 